\title{
PRODUCTIVITY AND SOIL FERTILITY STATUS AS INFLUENCED BY INTEGRATED USE OF N-FIXING BIOFERTILIZERS, ORGANIC MANURES AND INORGANIC FERTILIZERS IN ONION
}

\author{
P.K.S. Jayathilake ${ }^{1}$, I.P. Reddy ${ }^{2}$, D. Srihari ${ }^{2}$ and K.R.Reddy ${ }^{2}$
}

\begin{abstract}
One of the major constraints associated with onion (Allium cepa L.) cultivation is improper nutrient management. This necessitates to ascertain an efficient and economical integrated approach with renewable source such as organic manure and biofertilizers. In this context a field experiment was carried out at Acharya N.G.Ranga Agricultural university, Hyderabad, India to study the productivity and soil fertility status as influenced by integrated nutrient management in onion using $c v$. $N-53$. The twelve treatments arranged in randomized complete block design which consisted of two kinds of organic manure i.e. farmyard manure (FYM) and vermicompost (VC) alone and in combination with two kinds of bio fertilizers (Azotobacter chroococum and Azospirillum brasilianse) and chemical fertilizers which were tested in comparison with recommended dose of fertilizers (RDF) as control. The amount of FYM and vermicompost applied was calculated on the basis of their results of chemical analysis for NPK. Roots were dipped into the slurry of biofertilizer (1 $\mathrm{kg}$ in 10 liters) for 20 minutes before planting and thirty days after transplanting the soil between the seedling rows was also treated with biofertilizers at the rate of $2 \mathrm{~kg}$ per ha. Productivity indicated by yield and harvest index and soil fertility indicated by available NPK in soil after harvest were significantly increased with the application of biofertilizer in combination with $50 \% \mathrm{~N}$ through organic manure (FYM or VC) and rest of 50\% $\mathrm{N}$ and $100 \% \mathrm{PK}$ through chemical fertilizer. Those were significantly superior to the application of $50 \%$ recommended $N$ through organic manure with 50\% $\mathrm{N}$ and 100\% PK through chemical fertilizer, application of chemical fertilizer (control) alone and application of organic manure alone, respectively. Judicious application of bio fertilizers, organic manure and chemical fertilizer increased 22\% more yield over control (RDF) and economic analysis revealed that highest net return and benefit cost ratio obtained when FYM used as an organic source which replaced the 50\% of recommended dose of inorganic nitrogen. Bacterial population of Azotobacter and Azospirillum in soil after harvest was markedly increased with integrated use of bio fertilizer, organic manure and chemical fertilizer system and was reduced with the exclusive application of chemical fertilizers. The results indicated that integrated nutrient management with biofertilizer (Azotobacter and Azospirillum) in combination with 50\% inorganic $N$ through organic manure (VC or FYM) and rest of the $N$ and PK through chemical fertilizer is considered most useful for obtaining maximum yield with higher fertility status in soil for onion cultivation.
\end{abstract}

Key words: Biofertilizer, Azotobacter, Azospirillum, Onion (Allium cepa L.), Organic manure, soil fertility

\footnotetext{
${ }^{I}$ Regional Agricultural Research and Development Centre, Diyatalawa Road,Bandarawela,Sri Lanka

${ }^{2}$ Department of Horticulture, College of Agriculture, Acharya N.G.Ranga Agricultural University, Hyderabad, India
} 


\section{INTRODUCTION}

Onion is a most important bulb crop grown on commercial scale both for local consumption and export. The productivity of onion crop in India (10.6 t ha $\left.{ }^{-1}\right)$ and Sri Lanka (12.5 $\mathrm{t} \mathrm{ha}^{-1}$ ) is low compared to other countries. i.e. Korea $61.9 \mathrm{t} \mathrm{ha}^{-1}$, China $61.7 \mathrm{t} \mathrm{ha}^{-1}$, Australia (44.5 $\left.\mathrm{t} \mathrm{ha}^{-1}\right)$ and USA (42.9 t $\mathrm{ha}^{-1}$ ) (Panday and Bhonde, 1999). Among the constraints associated with the low yield, the role of nutrients is of paramount importance in boosting productivity and quality of onion.

Onion is a heavy feeder of mineral elements. A crop of $35 \mathrm{t} \mathrm{h}^{-1}$ removes approximately $120 \mathrm{~kg}$ of $\mathrm{N}, 50 \mathrm{~kg}$ of $\mathrm{P}_{2} \mathrm{O}_{5}$ and $160 \mathrm{~kg}$ of $\mathrm{K}_{2} \mathrm{O}$ per ha (Tandon, 1987). Hence the greater its ability to utilize nutrients for crop production, the greater is the yield potential.

Requirement of the nutrients has increased to many folds with the adoption of improved technology for obtaining higher yields per unit area, the requirements of the nutrients have increased to many folds. Continuous use of inorganic fertilizers resulted in deficiency of micronutrients, imbalance in soil physicochemical properties and unsustainable crop production.

With the increased cost of inorganic fertilizers, application of recommended dose is difficult to be afforded by the small and marginal farmers. Hence renewable and low cost sources of plant nutrients for supplementing and complementing chemical fertilizers should be substituted which can be affordable to the majority of farming community. In this context, integrated nutrient management would be a viable strategy for advocating judicious and efficient use of chemical fertilizers with matching addition of organic manures and biofertilizers.

Farmyard manure is a conspicuous organic component of an integrated nutrient supply system, which improves soil health, increases the productivity and releases macro and micronutrients. The compost produced by using earthworms commonly called vermicompost is a rich source of macro and micro nutrients, vitamins, growth hormones etc. (Kale et.al., 1992). Vermicompost plays a significant role in improving the fertility of topsoil and in boosting the productivity of the crop. It was reported that quality of onion and its' keeping quality were improved by the application of vermicompost (Gupta et al., 1999).

Bio-fertilizers refer to living organisms, which augment plant nutrient supplies in symbiotic or asymbiotic way. Among the asymbiotic, nitrogen fixing-bacteria, Azotobacter and Azospirillum contribute to significant improvement in crops yield by $15-20$ per cent while reducing the depletion of soil nutrients (Motsara et al., 1995). In addition to these beneficial effects, biofertilizers allow the saving of at least $20-30 \mathrm{~kg} / \mathrm{ha}$ inorganic $\mathrm{N}$ fertilizers, as they possess a tremendous potentiality in nitrogen fixation (Tilak, 1991).

Therefore, an investigation was undertaken to determine the effect of integrated nutrient management with bio fertilizer, organic manure and inorganic fertilizers on the productivity of onion and the soil fertility status.

\section{MATERIALS AND METHODS}

A field experiment was carried out on sandy loam soil during rabi (cool season) 2001-2002 at Acharya N.G. 
Ranga Agricultural University, Hyderabad in India. The experiment was arranged in a randomized complete block design with three replications using onion cv. N-53. Spacing adopted was $15 \times 10 \mathrm{~cm}$ and gross plot size was $3 \times 3 \mathrm{~m}\left(9 \mathrm{~m}^{2}\right)$. In the 12 treatments, two types of organic manures (farmyard manure and vermicompost) alone and in combination with two biofertilizers as commercial inoculants (Azotobacter chroococcum and Azospirillum brasilianse) and chemical fertilizers were tested. The recommended dose of chemical fertilizers (RDF) served as control (Table 01).

Table 01: Description of the treatments

Treatment No. Treatment

\begin{tabular}{ll}
$\mathrm{T}_{1}$ & Farmyard manure (FYM) $-20 \mathrm{t} / \mathrm{ha}$ \\
$\mathrm{T}_{2}$ & Vermicompost $(\mathrm{VC})-5 \mathrm{t} / \mathrm{ha}$ \\
$\mathrm{T}_{3}$ & Farmyard manure $-10 \mathrm{t} / \mathrm{ha}+\mathrm{Vermicompost}-2.5 \mathrm{t} / \mathrm{ha}$ \\
$\mathrm{T}_{4}$ & $50 \%$ recommended $\mathrm{N}$ through $\mathrm{FYM}+50 \%$ recommended N and \\
& total recommended $\mathrm{P}$ and $\mathrm{K}$ through chemical fertilizers \\
$\mathrm{T}_{5}$ & $50 \%$ recommended $\mathrm{N}$ through Vermicompost $+50 \%$ \\
& recommended $\mathrm{N}$ and total recommended $\mathrm{P}$ and $\mathrm{K}$ through \\
$\mathrm{T}_{6}$ & chemical fertilizers. \\
$\mathrm{T}_{7}$ & Treatment $3+$ Azotobacter $(2 \mathrm{~kg} / \mathrm{ha})$ \\
$\mathrm{T}_{8}$ & Treatment $4+$ Azotobacter $(2 \mathrm{~kg} / \mathrm{ha})$ \\
$\mathrm{T}_{9}$ & Treatment $5+$ Azotobacter $(2 \mathrm{~kg} / \mathrm{ha})$ \\
$\mathrm{T}_{10}$ & Treatment $3+$ Azospirillum $(2 \mathrm{~kg} / \mathrm{ha})$ \\
$\mathrm{T}_{11}$ & Treatment $4+$ Azospirillum $(2 \mathrm{~kg} / \mathrm{ha})$ \\
$\mathrm{T}_{12}$ & Treatment $5+$ Azospirillum $(2 \mathrm{~kg} / \mathrm{ha})$ \\
& Recommended NPK $(150-80-100) \mathrm{kg} / \mathrm{ha}$ (control) \\
\hline
\end{tabular}

Well-decomposed farmyard manure (FYM) and vermicompost (VC) were applied in respective treatments plot incorporated to the soil with hand rake. As per chemical analysis, NPK content in $\mathrm{VC}$ was reported as $1.96,1.45$ and 1.16 per cent respectively while NPK content in FYM was $0.56,0.21$ and 0.45 per cent, respectively. The amount of FYM and vermicompost applied was calculated on the basis of the results of analysis for NPK.

Roots of onion seedlings were dipped into the slurry of biofertilizer $(1 \mathrm{~kg}$ of inoculum of water in 10 liters) for 20 minutes before planting. Thirty days after transplanting the soil between the seedling rows was also treated with biofertilizers at the rate of $2 \mathrm{~kg}$ per ha.

Yield and harvest index (economic yield/biological yield $\mathrm{x} 100)$ were recorded in each treatment (Table 02). Soil samples collected from each plot before planting and after harvest of crop were analyzed to estimate the NPK status in soil and were subjected to estimate the population of Azotobacter and Azospirillum using spread plate method as described by Mohankumar and Reddy (1990). 
Table 02: Bulb yield (t/ha) and Harvest Index (\%) as influenced by different Biofertilizer, Organic Manure and chemical fertilizers in onion

\begin{tabular}{|c|c|c|}
\hline Treatments & Bulb yield $\left(\mathrm{t} \mathrm{ha}^{-1}\right)$ & Harvest Index (\%) \\
\hline $\mathrm{T}_{1}: \mathrm{FYM} 20 \mathrm{t} / \mathrm{ha}$ & 16.8 & 54.4 \\
\hline $\mathrm{T}_{2}: \mathrm{VC} 5 \mathrm{t} / \mathrm{ha}$ & 18.8 & 55.8 \\
\hline $\mathrm{T}_{3}: \mathrm{FYM} 10 \mathrm{t} / \mathrm{ha}+\mathrm{VC} 2.5 \mathrm{t} / \mathrm{ha}$ & 17.3 & 54.5 \\
\hline $\begin{array}{c}\mathrm{T}_{4}: 50 \% \mathrm{~N} \text { through FYM+ } \\
50 \% \mathrm{~N} \text { and } 100 \% \mathrm{PK} \\
\text { (Chemical fertilizer) }\end{array}$ & 35.8 & 64.7 \\
\hline $\begin{aligned} \mathrm{T}_{5}: & 50 \% \mathrm{~N} \text { through } \mathrm{VC}+ \\
& 50 \% \mathrm{~N} \text { and } 100 \% \mathrm{PK} \\
& \text { (Chemical fertilizer) }\end{aligned}$ & 37.4 & 65.6 \\
\hline $\mathrm{T}_{6}: \mathrm{T}_{3}+$ Azotobacter & 24.2 & 59.4 \\
\hline $\mathrm{T}_{7}: \mathrm{T}_{4}+$ Azotobacter & 38.9 & 65.3 \\
\hline $\mathrm{T}_{8}: \mathrm{T}_{5}+$ Azotobacter & 40.7 & 66.9 \\
\hline $\mathrm{T}_{9}: \mathrm{T}_{3}+$ Azospirillum & 23.8 & 61.0 \\
\hline $\mathrm{T}_{10}: \mathrm{T}_{4}+$ Azospirillum & 39.4 & 65.2 \\
\hline $\mathrm{T}_{11}: \mathrm{T}_{5}+$ Azospirillum & 42.0 & 67.3 \\
\hline $\mathrm{T}_{12}: \mathrm{RDF}-\mathrm{NPK}$ (Control) & 34.3 & 63.3 \\
\hline LSD at $5 \%$ & 1.45 & 1.69 \\
\hline $\mathrm{CV} \%$ & 12.2 & 10.5 \\
\hline
\end{tabular}

Soil $\mathrm{pH}$ of the experimental site was 6.1 and electrical conductivity was 2.3 $\mathrm{m}$ mhos $\mathrm{cm}^{-1}$. Textural class was sandy loam and the available $\mathrm{N}, \mathrm{P}$ and $\mathrm{K}$ amounts were recorded as 204.6, 24.5 and $146.5 \mathrm{~kg}$ per ha, respectively.

Economic analysis was performed to calculate net return and the benefit cost ratio with respect to each treatment.

\section{RESULTS}

\section{Bulb yield}

Application of Azospirillum in combination with $\mathrm{VC}$ and chemical fertilizers $\left(T_{11}\right)$ recorded significantly highest bulb yield (42.0 $\mathrm{t} \mathrm{ha}^{-1}$ ) which was on a par with the bulb yield (40.7t/ha) recorded with Azotobacter in the same combination of fertilizers $\left(\mathrm{T}_{8}\right)$.

Application of Azospirillum or Azotobacter in combination with FYM and chemical fertilizers i.e.,
$\mathrm{T}_{10}$ and $\mathrm{T}_{7}$ recorded significantly lower bulb yield (39.4 and 38.9 t/ha, respectively) than $T_{11}$ and $T_{8}$ but were on a par with each other.

Application of $\mathrm{VC}$ alone $\left(\mathrm{T}_{2}\right)$ has produced significantly higher bulb yield (18.8 $\mathrm{t}$ ha) than the sole application of FYM $\left(\mathrm{T}_{1}\right)$ or combined application of FYM and VC $\left(\mathrm{T}_{3}\right)$ which recorded the lowest bulb yield (16.8 and $17.3 \mathrm{t} / \mathrm{ha}$, respectively) among all the treatments.

Use of $50 \% \mathrm{~N}$ of RDF through VC in combination with chemical fertilizer $\left(T_{5}\right)$ produced significantly higher bulb yield (37.4 t/ha) than the $50 \% \mathrm{~N}$ through FYM in combination with chemical fertilizer $\left(\mathrm{T}_{4}\right)$ which recorded $35.87 \mathrm{t} / \mathrm{ha}$. On the other hand, the treatment with RDF (control) recorded a bulb yield of $34.34 \mathrm{t} / \mathrm{ha}$, which was significantly lower than the above organic amendments combined with chemical fertilizers $\left(\mathrm{T}_{5}\right.$ and $\left.\mathrm{T}_{4}\right)$. 


\section{Harvest Index (HI)}

Application of Azospirillum in combination with $\mathrm{VC}$ and chemical fertilizers $\left(T_{11}\right)$ recorded significantly highest harvest index $(67.3 \%)$, which was on a par with Azotobacter combined with the same fertilizers $\left(\mathrm{T}_{8}\right)$ which recorded a harvest index of $66.9 \%$.

On the other hand, Azospirillum in combination with FYM and chemical fertilizers $\left(\mathrm{T}_{10}\right)$ and Azotobacter with the same combination $\left(\mathrm{T}_{7}\right)$ have recorded HI of 65.2 and 65.3 per cent, respectively, which were on a par with each and were significantly lower than the above treatments $\left(\mathrm{T}_{8}\right.$ and $\left.\mathrm{T}_{11}\right)$.

The lowest HI (54.4\%) was recorded with the application of FYM $\left(\mathrm{T}_{1}\right)$ followed by VC $\left(\mathrm{T}_{2}\right)$ and FYM combined with VC $\left(\mathrm{T}_{3}\right)(55.8$ and $54.5 \%$, respectively) and there was no significant differences among them. The plants receiving $50 \% \mathrm{~N}$ of RDF through $\mathrm{VC}\left(\mathrm{T}_{5}\right)$ and through FYM $\left(\mathrm{T}_{4}\right)$ in combination with chemical fertilizers recorded significantly higher HI (65.6 and $64.7 \%$, respectively) than the control $(63.1 \%)$.

\section{Available Nitrogen Status in the soil after harvest}

The available $\mathrm{N}$ in soil (Table 3) was increased with application of all organic and biofertilizers in combination with chemical fertilizers while recording maximum $(267.86 \mathrm{~kg} / \mathrm{ha})$ with the application of Azospirillum in combination with $\mathrm{VC}$ and chemical fertilizers $\left(\mathrm{T}_{11}\right)$ which was on a par with Azotobacter in the same combination $\left(\mathrm{T}_{8}\right)$.

Table 03: Available N, P and $\mathrm{K}$ status in soil (kg/ha) after harvest as influenced by different Biofertilizer, Organic Manure and chemical fertilizers in onion

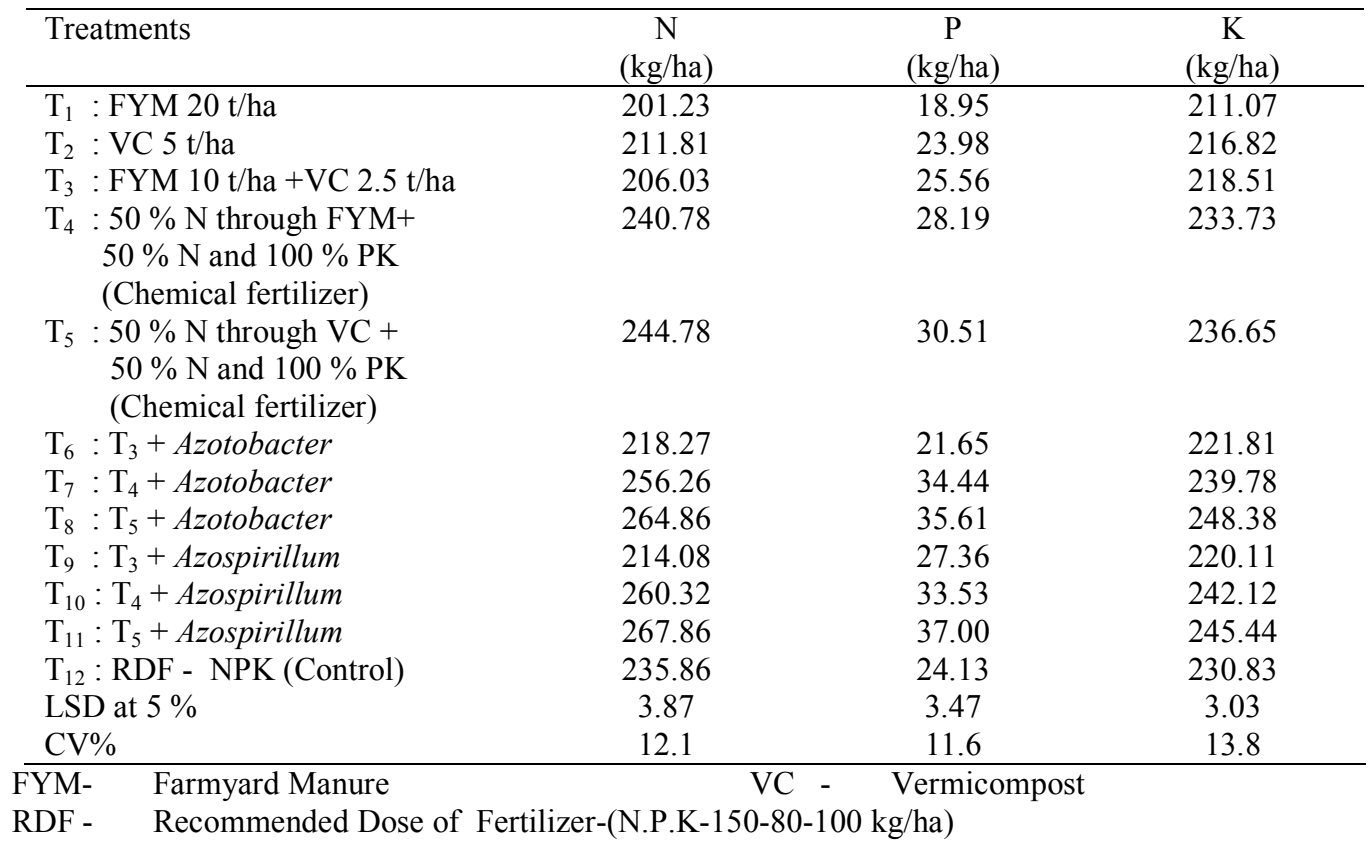


The lowest level of available $\mathrm{N}$ $(201.23 \mathrm{~kg} / \mathrm{ha})$ was recorded by application of FYM $\left(\mathrm{T}_{1}\right)$ and was significantly lower to the other organic manure treatments i.e, $\mathrm{VC}$ $\left(\mathrm{T}_{2}\right)$ and FYM with VC $\left(\mathrm{T}_{3}\right)$ which recorded 211.81 and $206.03 \mathrm{~kg} / \mathrm{ha}$, respectively.

Application of $50 \%$ recommended dose of $\mathrm{N}$ through FYM or VC and rest of the NPK fertilizers through chemical fertilizers i.e., $\mathrm{T}_{4}$ and $\mathrm{T}_{5}$ recorded significantly higher available N (240.78 and 244.78 $\mathrm{kg} / \mathrm{ha}$, respectively) over the RDF $(235.86 \mathrm{~kg} / \mathrm{ha})$ provided through chemical fertilizers.

\section{Available Phosphorus status in the soil after harvest}

The available phosphorus in soil increased with application of biofertilizers in combination with organic and chemical fertilizers (Table 3). Significantly higher available phosphorus (37.0 kg/ha) in soil was observed with the application of Azospirillum in combination with $\mathrm{VC}$ and chemical fertilizers $\left(T_{11}\right)$ which was on a par with Azotobacter in combination with VC and chemical fertilizer $\left(\mathrm{T}_{8}\right)$, Azotobacter in combination with FYM and chemical fertilizer $\left(\mathrm{T}_{7}\right)$ and Azospirillum with the same combination $\left(\mathrm{T}_{10}\right)$ which recorded available $P$ levels of $35.61,34.44$ and $33.53 \mathrm{~kg} / \mathrm{ha}$ respectively.

The onion crop supplied with only FYM $\left(T_{1}\right)$ recorded the significantly lowest value of available $P$ in soil after harvest i.e. $18.95 \mathrm{~kg} / \mathrm{ha}$.

Treatment with RDF (control) recorded $24.13 \mathrm{~kg} / \mathrm{ha}$ of available $\mathrm{P}$ which was significantly lower as compared to that of $50 \% \mathrm{~N}$ of $\mathrm{RDF}$ supplied through $\mathrm{VC}$ in combination with chemical fertilizer $\left(\mathrm{T}_{5}\right)$ and $50 \% \quad \mathrm{~N}$ through FYM in combination with chemical fertilizer $\left(\mathrm{T}_{4}\right)$ which recorded 30.51 and $28.19 \mathrm{~kg} / \mathrm{ha}$ of $\mathrm{P}$ respectively.

\section{Available Potassium status in the soil after harvest}

The maximum available amount of potash in the soil $(248.38 \mathrm{~kg} / \mathrm{ha})$ were recorded with Azotobacter in combination with $\mathrm{VC}$ and chemical fertilizers $\left(\mathrm{T}_{8}\right)$ which was on a par with Azospirillum with $\mathrm{VC}$ and chemical fertilizer $\left(\mathrm{T}_{11}\right) \quad(246.44$ $\mathrm{kg} / \mathrm{ha}$ ) which were significantly superior to the application of Azospirillum or Azotobacter with FYM and chemical fertilizers $\left(\mathrm{T}_{10}\right.$ and $\mathrm{T}_{7}$ ) which recorded the $\mathrm{K}$ values of 242.12 and $239.79 \mathrm{~kg} / \mathrm{ha}$ respectively.

The available $\mathrm{K}$ in the soil was significantly lowest $(211.07 \mathrm{~kg} / \mathrm{ha})$ with the application of FYM $\left(\mathrm{T}_{1}\right)$ followed by VC (216.82) and combination of both FYM and VC (218.51). The plants supplied with $50 \%$ recommended $\mathrm{N}$ through $\mathrm{VC}$ or FYM in combination with chemical fertilizers $\left(\mathrm{T}_{5}\right.$ and $\left.\mathrm{T}_{4}\right)$ recorded significantly higher values of $\mathrm{K} \quad(236.65$ and $233.73 \mathrm{~kg} / \mathrm{ha}$ respectively) over the recommended dose of chemical fertilizers (control).

\section{Azotobacter population in soil after harvest}

Significantly highest colony forming units (CFU) of Azotobacter was observed in Azotobacter inoculated with $20 \mathrm{t} / \mathrm{ha}$ of FYM and $2.5 \mathrm{t} / \mathrm{ha}$ of $\mathrm{VC}\left(\mathrm{T}_{6}\right)(134.67 \mathrm{x}$ $10^{4} \mathrm{CFU}$ per $\mathrm{g}$ soil) followed by Azotobacter in combination with $\mathrm{VC}$ and chemical fertilizers $\left(\mathrm{T}_{8}\right)$ and Azotobacter in combination with 
FYM and chemical fertilizers $\left(\mathrm{T}_{7}\right)$ which recorded $133.33 \times 10^{4}$ and $126.67 \times 10^{4} \quad \mathrm{CFU} / \mathrm{g}$ soil respectively with no significant difference (Table 4).

Table 04 : Population of Azotobacter and Azospirillum (CFU/g soil x 10 ${ }^{4}$ ) in soil after harvest as influenced by different Biofertilizer, Organic Manure and chemical fertilizers in onion cropping.

\begin{tabular}{|c|c|c|}
\hline Treatments & Azotobacter $\left(\mathrm{x} \mathrm{10^{4 } )}\right.$ & Azospirillum $\left(\times 10^{4}\right)$ \\
\hline $\mathrm{T}_{1}: \mathrm{FYM} 20 \mathrm{t} / \mathrm{ha}$ & $\begin{array}{l}12.53 \\
(350.74)\end{array}$ & $\begin{array}{l}11.67 \\
(341.56)\end{array}$ \\
\hline $\mathrm{T}_{2}: \mathrm{VC} 5 \mathrm{t} / \mathrm{ha}$ & $\begin{array}{l}22.66 \\
(476.09)\end{array}$ & $\begin{array}{l}21.00 \\
(458.26)\end{array}$ \\
\hline $\mathrm{T}_{3}: \mathrm{FYM} 10 \mathrm{t} / \mathrm{ha}+\mathrm{VC} 2.5 \mathrm{t} / \mathrm{ha}$ & $\begin{array}{l}19.66 \\
(443.47)\end{array}$ & $\begin{array}{l}18.33 \\
(428.14)\end{array}$ \\
\hline $\begin{array}{c}\mathrm{T}_{4}: 50 \% \mathrm{~N} \text { through } \mathrm{FYM}+50 \% \mathrm{~N} \text { and } \\
100 \% \mathrm{PK} \text { (Chemical fertilizer) }\end{array}$ & $\begin{array}{l}11.67 \\
(341.57)\end{array}$ & $\begin{array}{l}12.00 \\
(346.41)\end{array}$ \\
\hline $\begin{array}{c}\mathrm{T}_{5}: 50 \% \mathrm{~N} \text { through } \mathrm{VC}+50 \% \mathrm{~N} \text { and } \\
100 \% \mathrm{PK} \text { (Chemical fertilizer) }\end{array}$ & $\begin{array}{l}16.67 \\
(408.25)\end{array}$ & $\begin{array}{l}16.33 \\
(404.15)\end{array}$ \\
\hline $\mathrm{T}_{6}: \mathrm{T}_{3}+$ Azotobacter & $\begin{array}{l}134.67 \\
(1160.46)\end{array}$ & $\begin{array}{l}17.33 \\
(416.33)\end{array}$ \\
\hline $\mathrm{T}_{7}: \mathrm{T}_{4}+$ Azotobacter & $\begin{array}{l}126.67 \\
(1125.47)\end{array}$ & $\begin{array}{l}11.33 \\
(336.90)\end{array}$ \\
\hline $\mathrm{T}_{8}: \mathrm{T}_{5}+$ Azotobacter & $\begin{array}{l}133.33 \\
(1154.70)\end{array}$ & $\begin{array}{l}12.67 \\
(359.90)\end{array}$ \\
\hline $\mathrm{T}_{9}: \mathrm{T}_{3}+$ Azospirillum & $\begin{array}{l}16.00 \\
(400.00)\end{array}$ & $\begin{array}{l}137.33 \\
(1171.89)\end{array}$ \\
\hline $\mathrm{T}_{10}: \mathrm{T}_{4}+$ Azospirillum & $\begin{array}{l}13.67 \\
(369.72)\end{array}$ & $\begin{array}{l}125.33 \\
(1119.52)\end{array}$ \\
\hline $\mathrm{T}_{11}: \mathrm{T}_{5}+$ Azospirillum & $\begin{array}{l}16.33 \\
(404.14)\end{array}$ & $\begin{array}{l}133.67 \\
(1156.14)\end{array}$ \\
\hline $\mathrm{T}_{12}: \mathrm{RDF}$ - NPK (Control) & $\begin{array}{l}2.73 \\
(165.22)\end{array}$ & $\begin{array}{l}2.46 \\
(156.84)\end{array}$ \\
\hline Natural soil (check) & $\begin{array}{l}4.12 \\
(202.90)\end{array}$ & $\begin{array}{l}3.37 \\
(183.58)\end{array}$ \\
\hline $\begin{array}{l}\text { LSD at } 5 \% \\
\text { CV } \%\end{array}$ & $\begin{array}{l}42.51 \\
14.7\end{array}$ & $\begin{array}{l}34.14 \\
15.1\end{array}$ \\
\hline
\end{tabular}

FYM- Farmyard Manure

VC - Vermicompost

RDF - $\quad$ Recommended Dose of Fertilizer-(N.P.K-150-80-100 kg/ha)

CFU- Colony Forming units

- Values in parenthesis are square root of the observation.

- Colonies were counted at $10^{4}$ dilutions.

The lowest Azotobacter population $\left(1.73 \times 10^{4} \mathrm{CFU} / \mathrm{g}\right.$ soil) was recorded in control $\left(\mathrm{T}_{12}\right)$ which received recommended dose of chemical fertilizers, revealed that significantly lowest population of
Azatobacter as compared to rest of the treatments.

Azospirillum population in soil after harvest

The highest population of Azospirillum (137.33 x $10^{4} \mathrm{CFU} / \mathrm{g}$ 
soil) was recorded in the treatment with Azospirillum in combination with VC and FYM ( $\left.\mathrm{T}_{9}\right)$ followed by inoculation of Azospirillum with VC and chemical fertilizers $\left(\mathrm{T}_{11}\right)$ and the same with FYM and chemical fertilizers $\left(\mathrm{T}_{10}\right)$ which recorded $133.67 \times 10^{4}$ and $125.33 \times 10^{4} \mathrm{CFU}$ per $g$ soil respectively. All these treatments were on par with each other (Table 04).

The treatment with RDF (control) recorded the lowest population (1.46 × $10^{4} \mathrm{CFU} / \mathrm{g}$ soil) and was significantly lower to all the remaining treatments.
The treatments except control, those did not receive the inoculum of Azospirillum maintained the bacterial population of Azospirillum which were on par with one another.

\section{Net return}

Maximum net return of Indian Rs.49393.00 ( US \$ 1050.91 ) was recorded by the application of Azospirillum in combination with $50 \% \mathrm{~N}$ through FYM and the rest of $\mathrm{N}$ and $\mathrm{P} \mathrm{K}$ with chemical fertilizers $\left(\mathrm{T}_{10}\right)$ which was on a par with Azotobacter with same combination $\left(\mathrm{T}_{7}\right)$ (Figure01).

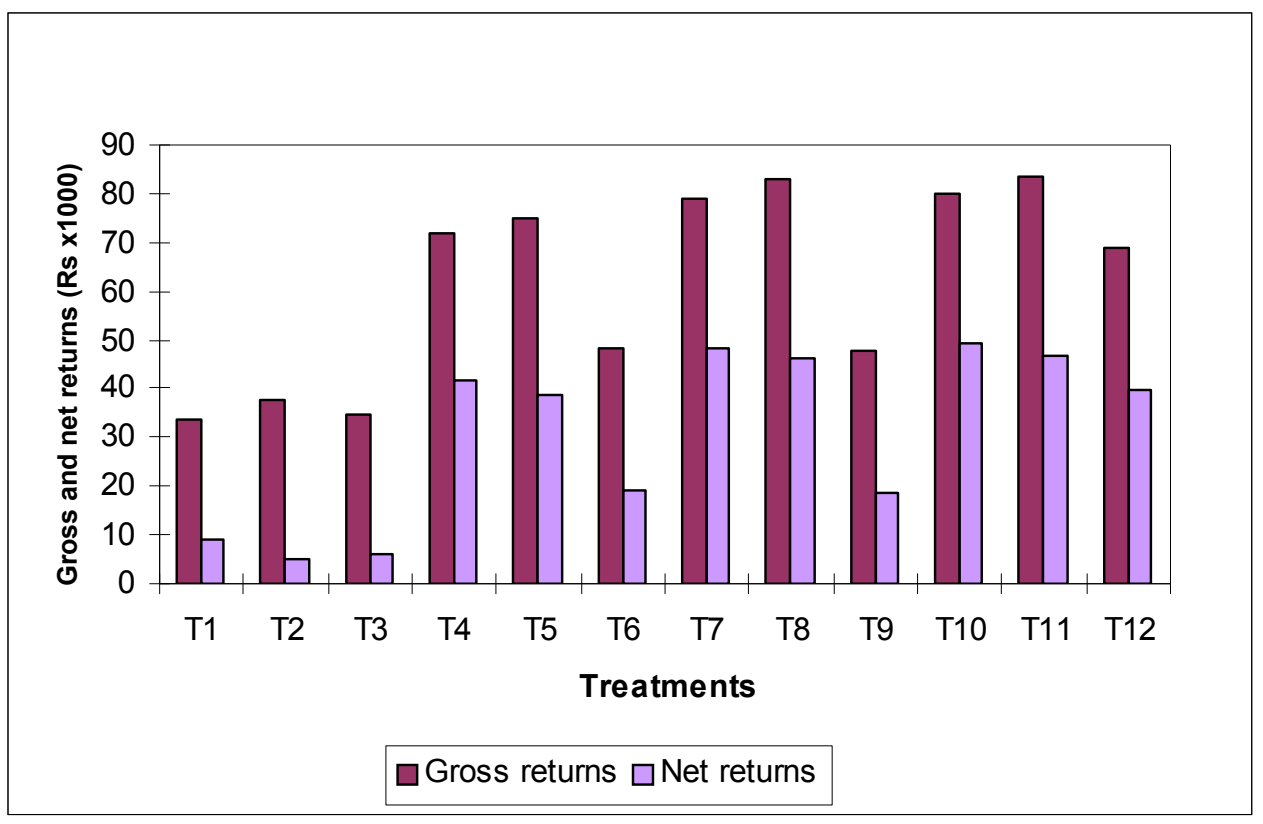

Figure 01: Gross and net returns (Indian Rs/ha) as influenced by different Biofertilizer Organic Manure and chemical fertilizers in onion

The lowest net return of Rs.5063.00 (US \$ 107.72) was obtained with $\mathrm{VC}\left(\mathrm{T}_{2}\right)$. The treatments receiving FYM $\left(\mathrm{T}_{1}\right)$ and the combined application of FYM and $\mathrm{VC}\left(\mathrm{T}_{3}\right)$ recorded significantly higher net returns of Rs.6070.00 (US \$ 129.15) and Rs.9298.00 (US \$ 197.85) respectively as compared to the application of $\mathrm{VC}$ alone. Application RDF recorded net returns of Rs.39733.00 (US \$ 845.38) which was on a par with plants receiving $50 \% \mathrm{~N}$ through FYM and rest of the $\mathrm{N}$ and $\mathrm{PK}$ 
through chemical fertilizers $\left(\mathrm{T}_{4}\right)$ and $50 \% \mathrm{~N}$ through $\mathrm{VC}$ with same combination $\left(\mathrm{T}_{5}\right)$ which recorded net return of Rs.41710.00 (US \$ 887.45 ) and Rs.38878.00 (US \$ $827.20)$ respectively.

\section{Benefit cost ratio}

Maximum benefit cost ratio (1.60) was recorded with application of
Azospirillum in combination with $50 \% \mathrm{~N}$ through FYM and rest of the $\mathrm{N}$ and $\mathrm{P} \quad \mathrm{K}$ through chemical fertilizers $\left(\mathrm{T}_{10}\right)$ followed by Azotobacter with same combination (1.57). The plants receiving $\mathrm{VC}$ alone $\left(T_{2}\right)$ recorded the lowest benefit cost ratio (0.16) (Figure.01 and 02).

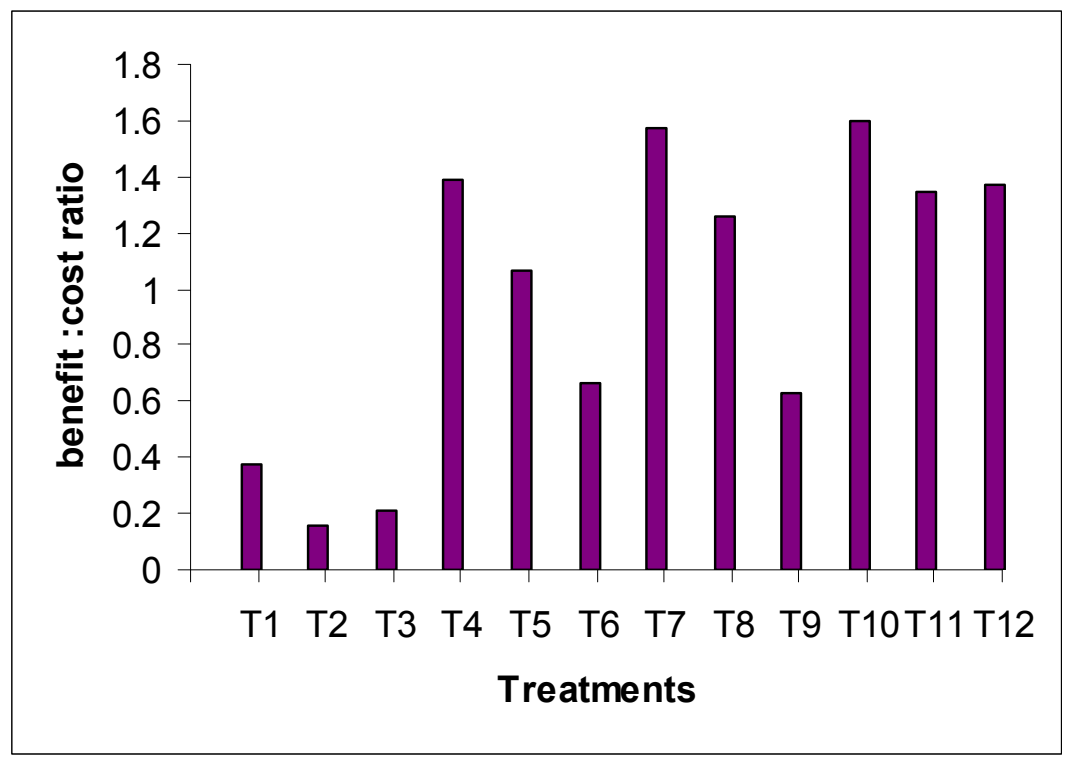

Figure 02: Benefit: cost ratio as influenced by different Biofertilizer, Organic manure and Chemical fertilizers in onion

Application of RDF (control) recorded a benefit cost ratio of 1.37 , which was higher than the treatments combination with $\mathrm{VC}$ $\left(\mathrm{T}_{5}, \mathrm{~T}_{8}\right.$ and $\left.\mathrm{T}_{11}\right)$.

\section{DISCUSSION}

The highest bulb yield and harvest index recorded with application of biofertilizers in combination with $\mathrm{VC}$ and chemical fertilizers $\left(\mathrm{T}_{11}\right.$ and $\left.\mathrm{T}_{8}\right)$ and $22.4 \%$ more yield over recommended dose of fertilizer was recorded with application of Azospirillum in combination with 50\% recommended $\mathrm{N}$ through $\mathrm{VC}$ and rest of NPK through chemical fertilizer $\left(\mathrm{T}_{11}\right)$.

Further, a significant reduction of yield was observed when VC was substituted with FYM i.e., Azospirillum in combination with FYM and chemical fertilizers $\left(\mathrm{T}_{10}\right)$ and Azotobacter in combination with FYM and chemical fertilizer $\left(\mathrm{T}_{7}\right)$. However, these treatments recorded 14.79 and 13.36 percent more yield than control respectively and revealed the beneficial effect of VC over FYM as described by Shinde et al,. (1992). 
Integrated use of biofertilizers, organic manure and chemical fertilizers resulted in yield increase in comparison with the exclusive application of chemical fertilizer. This could be due to the increase in nutrient availability and uptake of nutrients resulting in faster synthesis and translocation of photosynthate from source (leaves) to sink (bulb).

The decrease in HI with FYM $\left(\mathrm{T}_{1}\right)$, VC $\left(\mathrm{T}_{2}\right)$ or combined application of FYM and $\mathrm{VC}\left(\mathrm{T}_{3}\right)$ could be due to the fact that plant responded by producing proportionately more shoot and less bulb material. The differences of individual effect between Azotobacter and Azospirillum on bulb yield were estimated through comparison between treatments with Azospirillum with FYM and VC $\left(\mathrm{T}_{9}\right)$ and Azotobacter with FYM and VC $\left(\mathrm{T}_{6}\right)$ which revealed that individual effect of Azotobacter and Azospirillum was almost the same. This effect was in conformity with the results obtained by Jadhav et al., (1998).

Yield increase with biofertilizers in this integrated nutrient supply system with organic manure and chemical fertilizers was on an average of 9.5 per cent as compared to the system with organic manure and chemical fertilizer without biofertilizer.

Higher availability of NPK in soil with the treatment of biofertilizers in combination with VC or FYM and chemical fertilizer could be attributed to direct application of chemical fertilizer and release of $\mathrm{N}$ through $\mathrm{VC}$ or FYM and biological fixation of atmospheric $\mathrm{N}$ by bacterial fertilizers. $\mathrm{VC}$ is a better source of $\mathrm{N}$ and a good carrier material for Azospirillum and Azotobacter (Ismail, 1995) than the FYM (Shinde et al., 1992) and VC brought up the population of
Azospirillium and Azotobacter, which resulted in higher available NPK in the soil (Table 03 ).

Application of VC with chemical fertilizer $\left(T_{5}\right)$ recorded 7.73 per cent more $\mathrm{N}$ in soil over the FYM with chemical fertilizers $\left(\mathrm{T}_{4}\right)$ which indicated the favourable contribution of VC towards $\mathrm{N}$ content in soil.

Availability of $\mathrm{N}$ in soil increased on an average by 10.81 per cent with biofertilizer in combination with $\mathrm{VC}$ and chemical fertilizer $\left(T_{8}\right.$ and $\left.T_{11}\right)$ as compared to the same treatment without biofertilizers $\left(T_{5}\right)$. The lower values of available NPK in soil with chemical fertilizer (control) can be due to maximum utilization of applied nutrients by the crop, which were in the most available form. Reddy and Reddy (1998) also reported that available NPK content was increased by organic manure in combination with the chemical fertilizers.

The available $\mathrm{P}$ and $\mathrm{K}$ were highest in the treatments with Azospirillum, VC and chemical fertilizers in soil $\left(\mathrm{T}_{11}\right)$. The build up of available $\mathrm{P}$ and $\mathrm{K}$ in the soil could be due to the organic acids which were released during microbial decomposition of $\mathrm{VC}$ increasing the available $\mathrm{P}$ and $\mathrm{K}$ in soil (Khan et.al., 1994). There was no significant influence on $\mathrm{P}$ and $\mathrm{K}$ levels in soil by this biofertilizers. The applied $\mathrm{P}$ and $\mathrm{K}$ chemical fertilizer also enhanced the $\mathrm{P}$ and $\mathrm{K}$ availability in soil.

The treatments with significantly higher available NPK in soil $\left(\mathrm{T}_{7}, \mathrm{~T}_{8}\right.$, $\mathrm{T}_{10}$ and $\mathrm{T}_{11}$ ) recorded significantly higher bulb yield as compared to other treatments with low available NPK in soil.

The overall trend of the population of Azotobacter and Azospirillum in the 
soil after harvest of the onion crop clearly indicated that incorporating of organic manure alone or in combination with biofertilizers and chemical fertilizer significantly increased the population than the control (Table 04). Natural soil containing more bacterial population over the RDF revealed that sole application of chemical fertilizer affected the population of bacteria in natural soil. Application of Azotobacter in combination with FYM and $\mathrm{VC} \quad\left(\mathrm{T}_{6}\right)$ and application of Azotobacter in combination with FYM or $\mathrm{VC}$ with chemical fertilizers $\left(\mathrm{T}_{7}\right.$ and $\mathrm{T}_{8}$ ) increased the Azotobacter population most significantly compared to rest of the treatments while similar results were followed by Azospirillum with the same combinations $\left(\mathrm{T}_{9}, \mathrm{~T}_{11}\right.$ and $\left.\mathrm{T}_{10}\right)$. This could be due to rapid multiplication of bacteria applied through seedling root dip and soil application in preferable medium of organic manure, particularly vermicompost. In addition, vermicompost is inherently rich in microflora such as Azotobacter, Azospirillium and actinomycetes (Jambelkhar, 1994).

The organic manure (FYM or VC) increasing the mineral nutrients, growth hormones, vitamins and improving other physical characters in soil (Ismail, 1995) might have significant influence on microbial population.

The lowest population of these bacteria in the soil applied with chemical fertilizers (control) may be due to the absence of organic media in the soil and no simulative effect to increase the bacterial population. Occurrence of natural nitrogen fixing bacteria i.e., Aztobacter and Azospirillum in uninoculated organic treatments also showed the significantly higher value over the inorganic treatments. This is in conformity with the findings of Bhavalker (1991).

The higher yield of onion with those receiving Azospirillum or Azotobacter in combination with organic and chemical fertilizers against to their corresponding treatments without biofertilizer could be due to association with higher population of these $\mathrm{N}$ fixing bacteria in the soil which activated the more effective interaction with plant roots to ensure higher nutrient uptake (Ismail, 1995).

Significantly higher benefit cost ratio and net return were obtained by the application of biofertilizers in combination with $50 \% \quad \mathrm{~N}$ through FYM and rest of the $\mathrm{N}$ and $\mathrm{P}, \mathrm{K}$ through chemical fertilizers $\left(\mathrm{T}_{7}\right.$ and $\mathrm{T}_{10}$ ) over the $\mathrm{VC}$ in same combination $\left(T_{8}\right.$ and $T_{11}$ ) may be due to the low cost of FYM when compared to $\mathrm{VC}$ as reported by Reddy (2000).

Since the Treatments of control (RDF) and $50 \% \mathrm{~N}$ through $\mathrm{FYM}$ and rest of NPK through chemical fertilizers $\left(T_{4}\right)$ on a par with each other with respect to the benefit cost ratio and net return, it is better to use FYM as a low cost source of $\mathrm{N}$ by replacing $75 \mathrm{~kg}$ of N/ha of chemical fertilizers to get the benefits of higher yield and improving soil fertility in onion crop.

Although highest yield was recorded with biofertilizer in combination with vermicompost and chemical fertilizers, the high cost of $\mathrm{VC}$ resulted in the lower benefit cost ratio and net return as compared to recommended dose of fertilizers. In review of the highest net returns and highest benefit cost ratio, application of Azospirillum or Azotobacter in combination with FYM and chemical fertilizers may be recommended for cultivating onion. 


\section{CONCLUSIONS}

Integrated nutrient supply system with nitrogen fixing biofertilizers (Azospirillum or Azotobacter) in combination with organic manure (vermicompost and farmyard manure) and chemical fertilizers can be integrated to obtain optimum economical yield of onion, and to ensure the improvement of soil fertility with higher plant nutrients content and higher population of Azospirillum and Azotobacter as compared to application of presently recommended dose of chemical fertilizers for onion.

Among the different components, application of Azospirillum or
Azotobacter in combination with $50 \%$ recommended nitrogen $(75 \mathrm{~kg} / \mathrm{ha})$ through farmyard manure and rest of recommended nitrogen, phosphorous and potassium through chemical fertilizers could be practicable to obtain optimum productivity with higher benefit cost ratio in onion.

\section{ACKNOWLEDGEMENTS}

The authors wish to thank the Sri Lanka Council for Agricultural Research Policy for the financial assistance provided for this study and Mrs. N.K.P.K.Nagasinghe for her excellent job in typing.

\section{References}

Bhavalker, U.S., (1991.) Vermiculture Biotechnology for LEISSA seminar on low external input sustainable Agriculture, Amsterdam, Netherlands, pp. 1-6.

Gupta, R.P., V.P.Sharma, D.K. Singh, and K.J Srivastava., (1999.) Effect of organic manures and inorganic fertilizers on growth yield and quality of onion variety. Agrifound Dark Red NHRDF News Letter XIX (2\&3) pp. 7-9.

Ismail. S., (1995.) Earth worms in soil fertility management in organic agriculture (Ed: P.K.Thampan) Peekay Tree Crops Development Foundation, Cochin, pp.78-95.

Jambelkhar, H., (1994.) Bio organic farming, paper presented in the seminar on Development of Agriculture in Andhra Pradesh held on $4^{\text {th }}-5^{\text {th }}$ September 1994 of Hyderabad, pp. 1-6.

Jadhav, A.C. S.A. Memane and B.K. Konde,(1998.) Response of biofertilizers (diazotrophs) and nitrogen levels on sweet potato. Journal of Maharashtra Agricultural Universities, 23(3) : 245-248.

Khan, G., S.K. Gupta, and S.K. Banarg, (1994.) Studies on the solubilization of phosphorus in presence of different city wastes. Journal of Indian Society of Soil Science 29, pp 123-124.

Mohankumar, K.C. and R.S. Reddy, 1996. Agricultural Microbiology Laboratory manual. Kalyani Publishes, India, pp. 53.

Kale, R.D. B.C. Mallesh, K Bano, and D.J. Bagyaras, (1992.) Influence of vermicompost application on the available micronutrients and selected microbial population, Soil Biology and Biochemistry, 24(12), 1317 - 1320.

Motsara, M.R., P.Bhattacharya, and B. Srivastaba, , (1995.) Biofertiliser, Technology, marketing and usage. Fertilizer Development Consultation Organization, New Delhi, pp 183.

Panday, U.B. and S.R. Bhonde, , (1999.) Onion Export NHRDF news Letter XIX (4): 1-6. 
Reddy, G.B. and M.S. Reddy, , (1998.) Effect of organic manures and nitrogen levels on soil available nutrients in maize soya bean cropping system. Journal of Indian Society of Soil Science, 46(3), pp. 474-476.

Reddy, K.C., (2000.) Studies on integrated nutrient management with vermicompost and nitrogenous fertilizer in onion (Allium cepa L.)-Radish (Raphamus sativa L.) cropping system for sustainable crop production Ph.D. Thesis submitted to Acharys N.G. Ranbga University, Hyderabad. 172p

Shinde, P.H, R.L. Naik, , R.B. Nazikar, , S.K. Kandam, and V.M. Khaire, , (1992.) Evaluation of vermicompost. Proceedings of National Seminar on Organic Farming, MPKV, Pune, pp. 84.

Tandon, H.L.S., (1987.) Fertilizer recommendation for horticultural crops. A guide book, Fertilizer Development and Consultation Organization, New Delhi, pp. 10-14.

Tilak, K.V.B.R., (1991.) Bacterial fertilizers, Publication of Indian Council of Agricultural Research, New Delhi, pp. 65. 